九州大学学術情報リポジトリ

Kyushu University Institutional Repository

\title{
Relationship between Social Grooming and Agonistic Behaviour in a Stable Fattening Cattle Herd
}

Nakanishi, Yoshitaka

Kuju Agricultural Research Center, Faculty of Agriculture, Kyushu University

Shimizu, Yoshimasa

Laboratory of Forage Science and Animal Behaviour, Faculty of Agriculture, Kyushu University

Sumiyoshi, Youichi

Laboratory of Forage Science and Animal Behaviour, Faculty of Agriculture, Kyushu University

Kawamura, Toshihisa

Laboratory of Forage Science and Animal Behaviour, Faculty of Agriculture, Kyushu University 他

https://doi.org/10.5109/24025

出版情報：九州大学大学院農学研究院紀要. 37 (3/4)，pp. 325-329，1993-03. Kyushu University バージョン：

権利関係 : 


\title{
Relationship between Social Grooming and Agonistic Behaviour in a Stable Fattening Cattle $\mathrm{H}$ erd
}

\author{
Yoshitaka Nakanishi, Yoshimasa Shimizu*, Youichi Sumiyoshi*, \\ Toshihisa Kawamura*, Takafumi Goto* and Raizaburo Umetsu \\ Kuju Agricultural Research Center, Faculty of Agriculture, \\ Kyushu University 46-10, Oita 878-02, Japan \\ *Laboratory of Forage Science and Animal Behaviour, Faculty of Agriculture, \\ Kyushu University 46-06, Fukuoka 812, Japan
}

(Received November 30, 1992)

\begin{abstract}
A stable herd of fattening cattle comprising 9 steers and a heifer, which had been kept together over a month in a dry-lot, was observed for 13 days (0600-1900 h) to determine the diurnal distribution of the frequency of social licking interactions and to examine the relationship between social licking and agonistic behaviour. Agonistic behaviour was also classified into total (fighting, bunting, pushing, threatening and avoiding), aggressive (fighting, bunting, pushing and threatening) and physically aggressive (fighting, bunting and pushing) encounters. There were three major peaks in hourly distribution of social licking frequencies during the daytime, i.e. pre- and post-feeding in the morning (0700-0800 and $1000-1100 \mathrm{~h})$ and post-feeding in the afternoon (1600-1700 h). The frequency of social licking interactions was negatively correlated with total, aggressive or physically aggressive encounters, and there was a strong link between social licking and physically aggressive behaviour $(P<0.01)$. This indicates that social licking alternated with aggressive behaviour from day to day and served the function of controlling aggression in the socially stable herd.
\end{abstract}

\section{INTRODUCTION}

Cattle living in groups often groom each other and allogrooming (social licking) has been suggested to be an important behaviour which involves various hygienical and psychological functions to conspecifics (Brownlee, 1950; Hafez et al., 1969; Sambraus, 1969; Reinhardt, 1980; Arave and Albright, 1981; Hart, 1985; Sato et al., 1991a; Kabuga, 1992). In addition, positive relationships between social licking received and production traits have been demonstrated by dairy and beef cattle (Wood, 1977; Sato, 1984; Sato et al., 1991b). Thus, many workers studied behavioural, physiological and productive implications of social licking in domestic cattle.

Recently Kabuga et al. (1991) have reported that aggressive behaviour was not observed during grooming in 10 grazing cattle following re-grouping and suggested that grooming had the function of relaxing social tension, though no quantitative relationship between grooming and agonistic behaviour was demonstrated. Nakanishi et al. (1991), who found a short-term definite reciprocal relationship between social licking and agonistic interactions in a herd of beef breeding cows under a socially unstable situation subsequent to the introduction of a stranger, also implied that social licking was likely to offset conflict among animals. However, it has been unknown whether such relationship may be the case in other herds. In particular, there is little 
evidence to suggest a possible relationship between social licking and agonistic behaviour deriving from the relatively long-term observation in a socially stable herd of fattening cattle. The present study, therefore, was conducted to investigate the diurnal pattern of social licking interactions in a herd of Japanese Black fattening cattle under dry-lot feeding condition and to examine the extent to which social licking is related to agonistic events.

\section{MATERIALS AND METHODS}

A fattening herd of 10 dehorned Japanese Black Cattle were used for this study. The herd consisted of nine steers and a heifer ranging in age from 16 to 26 months. The animals were fed over a month in a dry-lot with space allowance of about $30 \mathrm{~m}^{2}$ per animal. Approximately $30 \%$ of the lot was covered with roof. Each animal received $3.5 \mathrm{~kg}$ concentrate twice a day $(0830$ and $1500 \mathrm{~h})$ at a stanchion manger in the lot and was allowed free access to grass hay at a two-sided hay rack $(4.5 \times 2.2 \mathrm{~m}, 2.7$ $\mathrm{m}$ in height) placed in the center of the lot. Water and salt were provided ad libitum.

Behavioural observations were made during 0600-1900 h for 13 days, exclusive of rainy or oestrous days for a period of 23 study days between 24 July and 16 August 1991. The weather during observation days was fine or cloudy and relatively stable. During the observation period, social licking interactions and agonistic behaviour were recorded whenever they occurred. Agonistic behaviour was categorized into total agonistic encounters (fighting, bunting, pushing, threatening and avoiding), aggressive behaviour (fighting, bunting, pushing and threatening) and physically aggressive behaviour (fighting, bunting and pushing) according to the definition of Dickson et al. (1967).

Chi-square $\left(\chi^{2}\right)$ analysis was used to study whether there was a particular deviation in observed frequencies of social licking within a day. Producttmoment (simple) correlation was used to examine the relationships between social licking and the categorized agonistic behaviours (Steel and Torrie, 1960).

\section{RESULTS AND DISCUSSION}

\section{Diurnal pattern of social licking}

A total of 459 social licking interactions was observed during 13 daytime periods. Figure 1 shows diurnal hourly variation in the social licking interactions within a fattening herd. There was considerable variation in social licking within a day exclusive of peri-feeding time $(0800-1000$ and $1500-1600 \mathrm{~h})$, and three peaks, i.e. 0700 0800, 1000-1100 and 1600-1700 h occurred ( $\chi^{2}$ test, $\left.P<0.01\right)$. The occurrence of the latter two peaks seems to be associated with delivery time of concentrate (0830 and $1500 \mathrm{~h}$ ). This concurs with the results of Sambraus (1969) and Wood (1977) who observed the intensive social licking occurred after feeding in loose housing dairy cattle. This pattern is also similar to the diurnal distribution of maternal licking interactions in a cow-calf group fed twice a day as presented by Nakanishi et al. (1993), who ascribed the occurrence of the intensive maternal licking to a psychological stability following satiation. Sato et al. (1991b) suggested similarly that social licking of milking cows in a loose barn was particularly frequent between 1630 and $1830 \mathrm{~h}$. However, the reason for the occurrence of relatively frequent social licking before the 
morning meal in this investigation was not clear.

\section{R elationship between social licking and agonistic behaviour}

Daily frequencies of social licking, total agonistic, aggressive and physically aggressive interactions in a fattening herd for 13 observation days are shown in Table 1. The frequency of social licking interactions per animal day was 3.5, a much larger

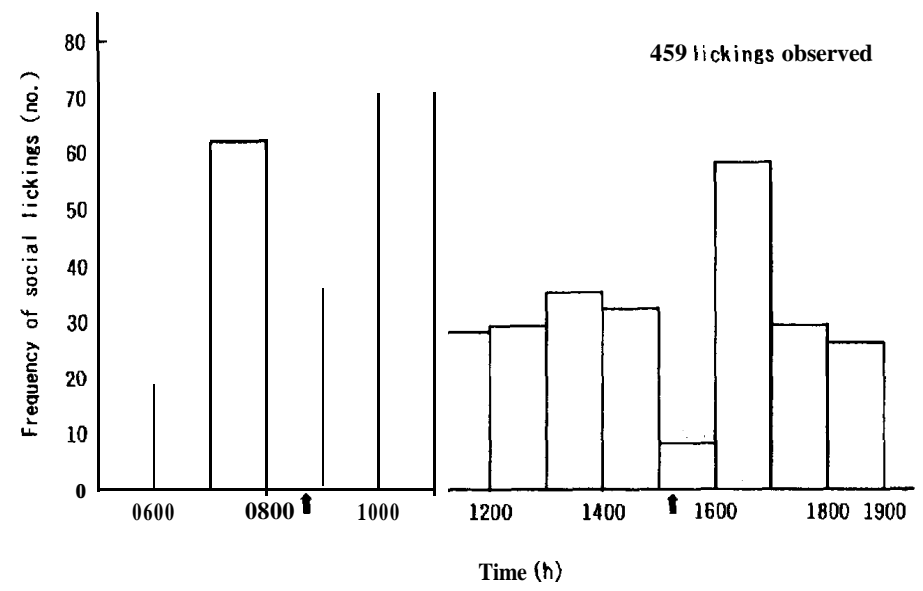

Fig. 1. Diurnal pattern of social lickings within a fattening herd during 13 observation days (exclusive of 0830-0900 and 1500-1530 h).

$\uparrow$ Feed (concentrate) delivery time.

Table 1. Daily frequency of social licking and agonistic interactions within a fattening herd during 13 observation days.

\begin{tabular}{|c|c|c|}
\hline Item & Mean & SD” \\
\hline Social licking (no.) & 35.3 & 5.9 \\
\hline Total agonistic encounters (no.)' & 123.1 & 33.4 \\
\hline Aggressive encounters (no.) $)^{3}$ & 87.2 & 22.4 \\
\hline Physically aggressive encounters (no.) ${ }^{4}$ & 68.2 & 17.5 \\
\hline
\end{tabular}

"Standard deviation.

${ }^{2}$ Fighting, bunting, pushing, threatening and avoiding.

${ }^{3}$ Fighting, bunting, pushing and threatening.

${ }^{4)}$ Fighting, bunting and pushing.

Table 2. Simple correlation coefficients between social licking and agonistic behaviours $(n=13)$.

\begin{tabular}{lc}
\hline & Social licking \\
\hline Total agonistic encouters & $-0.506^{\prime}$ \\
Aggressive encounters & $-0.579^{*}$ \\
Physically aggressive encounters & $-0.688^{* *}$ \\
\hline
\end{tabular}

${ }^{+} P<0.10,{ }^{*} P<0.05,{ }^{* *} P<0.01$. 
value than that of 0.3-0.9 for re-grouped cattle obtained by Kabuga et al. (1991). This result is likely to reflect the stability of social structure in this herd. However, the aggressive and physically aggressive forms of total agonistic encounters were 70.8 and $55.4 \%$, respectively, the latter being larger than the expected proportion (approximately $40 \%$ of total agonistic interactions) of physical interactions after stabilization of group formation of Holstein cows as indicated by Kondo and Hurnik (1990). Although the reason for this difference is difficult to explain, it may partly be caused by the difference in breed and/or sex of the animals between the two studies.

Coefficients of simple correlation between social licking and agonistic interactions are presented in Table 2. Social licking had negative correlations with each of the categorized agonistic behaviours. Especially, social licking was highly correlated with aggressive or physically aggressive encounters $(\mathrm{P}<0.05,0.01)$. A closer association of social licking and physically agonistic contacts rather than total agonistic contacts coincides with the findings of Nakanishi et al. (1991). Since the fattening cattle in this study had been individually provided concentrate using stanchion manger and adequate feeding space for roughage was available (more than $0.8 \mathrm{~m}$ per animal, which is close to the value recommended by Arave and Albright, 1981), there seems to be a small possibility of food competition under such feeding condition. Also, the cattle had been kept together in a lot with adequate space allowance $\left(30 \mathrm{~m}^{2} /\right.$ animal $)$ for more than one month. It is therefore likely that this herd formed a stable social structure. From these results, it was evident that social licking alternated with agonistic behaviour from day to day and thereby the former served the function of controlling the latter in a socially stable herd as well as an unstable group disrupted by a stranger (Nakanishi et al., 1991). In particular, physical aggression which is a severe agonistic behaviour, seemed to be controlled strongly by affiliative interaction such as allogrooming. This investigation convincingly sustains the theory of psychological effects of social grooming proposed by other workers (Reinhardt, 1980; Arave and Albright, 1981; Hart, 1985; Fraser and Broom , 1990; Kabuga et al., 1991; Sato et al., 1991a).

According to Thorpe (1969), the Brambell Committee in Great Britain, which was a technical committee to enquire into the welfare of animals kept under intensive livestock husbandry systems, advocated the importance of normal grooming as one of the basic freedoms in confined animals which should be allowed by stockpersons. Sambraus (1969) and Sato et al. (1991a) also found that grooming solicitation occurred in a cattle herd. Therefore, allogrooming as well as self-grooming is thought to be a manifestation of behavioural need in farm animals (Fraser and Broom, 1990), and from an animal welfare standpoint it is of vital importance to keep animals under feeding conditions which would promote the animals to groom normally rather than engage in agonistic activities. In the future, it is essential to develop management and housing systems which satisfy the needs not only of herdsmen but also of the animals themselves.

\section{ACKNOWLEDGEMENTS}

The authors wish to express their sincere thanks to Mr. T. Etoh of Kuju Agriculutural Research Center, Kyushu University for the care of experimental 
animals and technical assistance in this study. Thanks are also due to Mr. N. Koga at the Department of Animal Science, Faculty of Agriculture, Kyushu University for his help with observations. They especially pay a high tribute to Dr. C. W. Arave at the Department of Animal, Dairy and Veterinary Sciences, Utah State University for his kind reviewing the manuscript.

\section{REFERENCES}

Arave, C. W. and J. L. Albright 1981 Cattle behavior. J. Dairy Sci., 64: 1318-1329

Brownlee, A. 1950 Studies in the behaviour of domestic cattle in Britain. Bull. Anim. Behav., 8: 1120

Dickson, D. P., G. R. Barr and D. A. Wieckert 1967 Social relationships of dairy cows in a feed lot. Behaviour, 29: 195-203

Fraser, A. F. and D. M. Broom 1990 Fawn Animal Behaviour and Welfare. Baillière Tindall, London (United Kingdom)

Hafez, E. S. E., M. W. Schein and R. Ewbank 1969 The behavior of cattle. In "The Behavior of Domestic Animals", ed. by E. S. E. Hafez, Baillière Tindall \& Cassell, London, pp. 235-295

Hart, B. L. 1985 The Behavior of Domestic Animals. W. H. Freeman \& Company, New York (United States), pp. 15-81

Kabuga, J. D. 1992 Social interactions in N'dama cows during periods of idling and supplementary feeding post-grazing. Appl. Anim. Behav. Sci., 34: 11-22

Kabuga, J. D., J. Gari-Kwaku and S. Y. Annor 1991 Social status and its relationships to maintenance behaviour in a herd of N'dama and West African Shorthorn cattle. Appl.Anim. Behuv. Sci., 31: 169-181

Kondo, S. and J. F. Hurnik 1990 Stabilization of social hierarchy in dairy cows. Appl. Anim. Behuv. Sci., 27: 287-297

Nakanishi, Y., Y. Maehara, Y. Masuda and R. Umetsu 1993 Some behavioural aspects of cow-calf relationships in a herd of beef cattle in semi-confinement. J.Fac.Agr., Kyushu Univ., 37(3•4): 219-226

Nakanishi, Y., Y. Mutoh, Y. Masuda, R. Umetsu and I. Goto 1991 Social and spacing behaviour of Japanese Black Cattle after introducing a strange cow into a stable herd. J.Fac. Agr., Kyushu Univ., 36:1-11

Reinhardt, V. 1980 Social behaviour of Bos indicus. In "Behaviour in Relation to Reproduction, Management and Welfare of Farm Animals", ed. by M. Wodzicka-Tomaszewska, T. N. Edey and J. J. Lynch, University of New England, Armidale, N. S. W., pp. 153-156

Sambraus, H. H. 1969 Das soziale Lecken des Rindes. Z.Tierpsychol., 26: 805-810

Sato, S. 1984 Social licking pattern and its relationships to social dominance and liveweight gain in weaned calves. Appl. Anim. Behuv. Sci., 12: 25-32

Sato, S., S. Sako and A. Maeda 1991a Social licking patterns in cattle (Bos taurus): influence of environmental and social factors. Appl. Anim. Behuv. Sci., 32: 3-12

Sato, S., K. Tarumizu and T. Sonoda 1991b Social, behavioural and physiological functions of allogrooming in cattle. In "Applied Animal Behaviour: Past, Present and Future", ed. by M. C. Appleby, R. I. Horrell, J. C. Petherick and S. M. Rutter, UFAW, Herts, pp. 77-78

Steel, R. G. D. and J. H. Torrie 1960 Principles and Procedures of Statistics. McGraw-Hill Book Company, Inc., New York (United States)

Thorpe, W. H. 1969 Welfare of domestic animals. Nature, 224: 18-20

Wood, M. T. 1977 Social grooming patterns in two herds of monozygotic twin dairy cows. Anim. Behav., 25: 635-642 